\title{
Secularización, laicidad y fundamentalismo religioso en las sociedades occidentales contemporáneas: Algunos aportes para la discusión
}

Recibido: 27 de junio 2018 Revisado: 7 de septiembre 2018 Aprobado: 22 de octubre 2018 Andrey Pineda Sancho Costarricense. Licenciado en Sociología por la Universidad de Costa Rica, con estudios en filosofía y estudiante de la Maestría Académica en Historia de la misma universidad. Desde hace algunos años se desempeña como asistente e investigador en el Centro de Investigación en Cultura

y Desarrollo (CICDE) de la Universidad Estatal a Distancia (San José, Costa Rica); centro en el que ha procurado desarrollar, junto con el Dr. Dagoberto Núñez

Picado, una línea de estudios orientada a dar cuenta de los procesos de cambio sociorreligioso más sobresalientes en la Costa Rica de las últimas décadas. Correo electrónico: apineda@uned.ac.cr

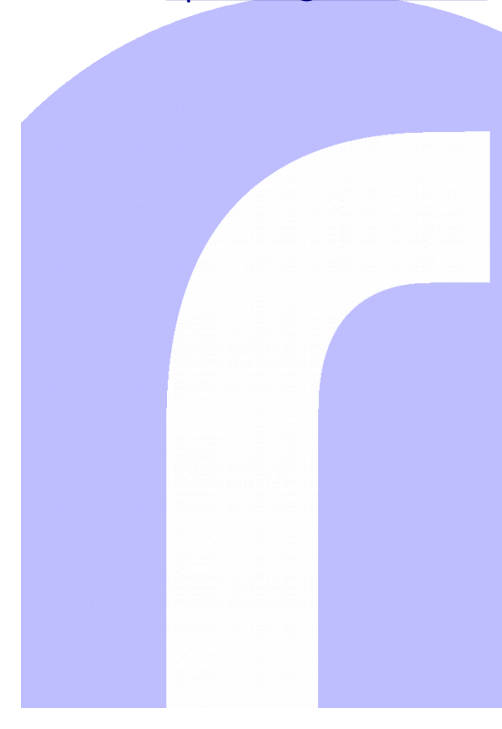

Resumen: En las últimas décadas, el mundo occidental ha conocido una singular revitalización religiosa. Lejos de desaparecer de los escenarios sociopolíticos o del ámbito vital más inmediato de las poblaciones, la religión no sólo ha mantenido muchas de sus antiguas atribuciones sociales, sino que, al mismo tiempo, ha encontrado nuevas vías de expresión. Ello, sin embargo, ha corrido de forma paralela al declive de la influencia sociocultural de las viejas instituciones religiosas y a la transformación generalizada de las estructuras del creer. Si bien el mundo de hoy aloja dentro de sí una oferta religiosa mucho más robusta y plural, lo cierto es que esta diversidad ha traído consigo una relativización de las distintas creencias, así como la posibilidad de que estas no pasen necesariamente por el control de las instituciones que históricamente han procurado decidir sobre sus contenidos. Así las cosas, el presente artículo pretende dibujar una vía de ingreso adecuada para comprender la confluencia de las dos tendencias descritas, pero sobre todo apta para escapar a las contradicciones empíricas que estas parecen sugerir.

Palabras clave: Secularización; laicidad; fundamentalismo religioso; pluralismo religioso; religión; modernidad

\section{Secularization, Laicism, and Religious Rundamentalism in Contemporary Societies: Reflections from Latin America}

Abstract: For the past few decades the western world has seen a particular religious revival. Far from disappearing from the socialpolitical scenarios or from the immediate vital scope of the population, religion has not only maintained much of its long-standing social power, but it has also found new routes of expression. However, this has happened at the same time as the decline of the social-cultural influence of outdated religious institutions and the general transformation of belief structures. Although the world today has a much more robust and varied religious offer, it cannot be denied this diversity has brought on a relativization of the different beliefs, as well as the possibility that these will not necessarily be under the control of the institutions that, throughout history, have aimed to control their content. Thus, this article intends to offer a gateway to help understand the confluence of the two trends described, and which is also apt to escape from the empirical contradictions these seem to suggest.

Key words: Secularization; laicism; religious fundamentalism; religious pluralism; religion; modernity 
Una forma de plantear la pregunta que pretendo responder aquí es: ¿por qué en nuestra sociedad occidental era virtualmente imposible no creer en Dios en el año 1500, por ejemplo, mientras que en el 2000 eso no sólo es fácil para muchos de nosotros, sino incluso inevitable?

Charles Taylor, La era secular.

\section{Introducción}

1. Temporalmente nos estaremos refiriendo sobre todo al llamado período tardío del moderno sistema-mundo capitalista, es decir, a la etapa de su despliegue que va desde el final de la Segunda Guerra Mundial, en 1945, hasta la actualidad. Sin embargo, para enmarcar adecuadamente la comprensión de este período, a lo largo del artículo haremos constantes alusiones al desarrollo general de la época moderna, desde sus inicios, en 1492, hasta la década que está pronta a finalizar. Para obtener una visión global acerca del origen y el devenir histórico del moderno sistema-mundo capitalista, véase: Dussel, Enrique. 2004. «Modernidad, imperios europeos, colonialismo y capitalismo. Para entender el proceso de la transmodernidad». Ponencia presentada en la Universidad de Chicago, 24 de abril de 2004.
El presente artículo tiene la intención de ofrecer insumos capaces de abonar, tanto a la comprensión científico-filosófica del fenómeno religioso en las sociedades contemporáneas como a las discusiones que han sido detonadas, en los últimos lustros, por la irrupción de los fundamentalismos religiosos en los escenarios políticos de todo el mundo occidental y, en particular, de los países latinoamericanos y caribeños. Desde una perspectiva primordialmente teórica, mas no desinformada ni desprendida del mundo empírico, nos damos a la tarea de exponer y problematizar no sólo algunos de los rasgos más sobresalientes del panorama religioso prevaleciente en las sociedades de hoy, ${ }^{1}$ sino sobre todo de discutir, en términos muy sintéticos, las líneas generales de los distintos modelos interpretativos que han procurado captar las particularidades de este panorama, así como establecer un diagnóstico convincente sobre el lugar que ocupa lo religioso en los ordenamientos sociales modernos y sobre las capacidades de incidencia social, política, económica y cultural que hoy ostentan las instituciones religiosas, por un lado, y las creencias y prácticas religiosas, por el otro. Juzgamos conveniente adelantar que a nuestro criterio muchos de estos abordajes y diagnósticos tienden a ser por lo menos ambiguos en sus apreciaciones; entre otras cosas porque pierden de vista tanto la complejidad constitutiva de los fenómenos analizados como la mirada de largo alcance temporal que posibilitaría dimensionar con mucha mayor propiedad el rol que ejerce lo religioso dentro de los distintos universos sociales del mundo occidental actual.

Como alternativa a estas propuestas, procuramos desarrollar un marco interpretativo que permita comprender de forma cabal la emergencia y el desarrollo simultáneo de fenómenos tan contrastantes como lo podrían ser la aparición de nuevas formas de religiosidad vs. la pérdida relativa de hegemonía de las instituciones religiosas tradicionales; la (re)politización de nuevas y viejas agrupaciones religiosas vs. la autonomización práctica de los aparatos estatales; o bien, el surgimiento intempestivo de los fundamentalismos religiosos vs. la configuración de sociedades cada vez más plurales desde el punto de vista cultural, moral y axiológico. En último término, nuestro esfuerzo no persigue mayor propósito que el de tratar de explicar cómo es posible que procesos aparentemente tan contradictorios puedan confluir incluso den- 
tro de un mismo espacio social (país, nación, etc.) o, mejor dicho, cómo es posible que nuestros modernos ordenamientos sociales, secularizados como se han querido asumir y presentar, den pie a la aparición o a la persistencia de prácticas culturales (religiosas, políticas, etc.) que en no pocas ocasiones solemos considerar como pertenecientes a otros períodos de la historia. El problema con las lecturas parciales es que suelen concentrarse únicamente en alguna de las tendencias anteriormente descritas; así, quienes deseen focalizarse en las primeras, verán al mundo como un lugar colmado en todas sus dimensiones por imaginarios y símbolos de tipo religioso y quienes opten, en contraste, por hacer énfasis en las segundas, más bien tenderán a concebir la evolución de nuestras sociedades como una marcha inexorable hacia el declive y la pérdida de relevancia absoluta de las expresiones religiosas.

Para cumplir nuestro cometido, decidimos desplegar la argumentación en cinco partes. En un primer momento ofrecemos una aproximación muy breve y general a los procesos e indicadores que nos hablan de la existencia de un reavivamiento religioso en las sociedades occidentales contemporáneas; en un segundo momento, emprendemos una sucinta discusión con aquellos diagnósticos que ven en dicho reavivamiento tanto el retorno a ordenamientos sociopolíticos de corte pre-moderno como el fracaso concomitante de las propuestas teórico-filosóficas que han asociado modernidad con secularización, para pasar de forma inmediata a proponer, en un tercer momento, una vía interpretativa capaz de integrar, en una misma clave analítica, la compresión de los paradójicos procesos a los que nos hemos referido líneas atrás. En cuarto lugar, exponemos algunas de las amenazas sociales que han traído consigo los proyectos político-religiosos de cariz fundamentalista y, por último, tratamos de sugerir posibles formas de enfrentar tales amenazas.

\section{El reavivamiento religioso en el mundo occidental contemporáneo}

En los últimos años, el planeta entero, prácticamente sin excepción, ${ }^{2}$ ha sido testigo de una evolución sin precedentes en el comportamiento del fenómeno religioso o, más bien, de aquel conjunto de fenómenos, no siempre equiparables en todas sus dimensiones, pero usualmente homologados a partir analogías de discutible precisión, a los que genéricamente etiquetamos con el nombre de religiosos.

Muy a pesar del decaimiento generalizado de la práctica religiosa tradicional y del debilitamiento de las instituciones religiosas clásicas que, como tendencia global, han tenido lugar en las sociedades occidentales en el transcurso de los últimos cinco siglos, y que, durante no pocos momentos de la historia llevaron a anunciar con temeridad el agotamiento definitivo de este tipo de expresiones, lo que hoy día se observa no sólo es la persistencia (por supuesto no incólume) de la mayor parte de las manifestaciones religiosas históricas, sino también la aparición de nuevas o renovadas formas de práctica University Press.

2. Aunque el presente artículo centra su atención preponderantemente en las sociedades americanas ( $\mathrm{y}$ en particular latinoamericanas) y europeas noroccidentales, en países de otros continentes del orbe también es posible encontrar procesos de reavivamiento religioso similares a los que han alimentado las reflexiones que aquí desarrollamos. En África y en Asia, por ejemplo, millones de personas durante los últimos decenios no sólo han abrazado formas renovadas de islamismo, sino que al mismo tiempo le han abierto efusivamente las puertas al evangelicalismo pentecostal de origen norteamericano. Al respecto, puede consultarse: Freston, Paul. 2004. Evangelicals and politics in Africa, Asia and Latin America. New York: Cambridge 
3. Como ejemplos de esta reconfiguración religiosa, Frédéric Lenoir ([2003]2005, 11) cita el "florecimiento de nuevos movimientos religiosos, el desarrollo del pentecostalismo protestante y del movimiento católico de renovación carismática, las manifestaciones de reafirmación identitaria y comunitaria en el seno de los tres monoteísmos, el avance de los fundamentalismos y el despertar de las religiones en la escena política mundial, la atracción de las espiritualidades orientales, el renovado interés por la mística, la espiritualidad y la sabiduría filosóficas antiguas, el éxito creciente de los temas del movimiento New Age y el desarrollo del pensamiento mágico, de la astrología y de las prácticas adivinatorias".

4. Según el Pew Research Center $(2014,27)$, por ejemplo, mientras en el año 1950 la población protestante (de distintas denominaciones) a nivel latinoamericano apenas si representaba el $3 \%$ de la población total del subcontinente, para el 2014, su porcentaje de representación se había elevado ya hasta el $19 \%$. El porcentaje de católicos y católicas dentro del conjunto de la región, por su parte, pasó del $94 \%$ del total poblacional en 1950 , al $69 \%$ en el año 2014. y creencia religiosa. ${ }^{3}$ Ello ha sido así tanto en los países centrales como en los periféricos del moderno sistema-mundo capitalista. Es decir, tanto en aquellos países a los que se les considera o consideraba la encarnación por antonomasia del ethos propiamente moderno, como en aquellas naciones a las que se les suele considerar, según creemos de forma equivocada, solo parcialmente modernas o en vías de llegar a serlo.

En el primero de los casos, en que el representante por excelencia es la Europa noroccidental, se constata la perseverancia de prácticas y creencias religiosas más allá de los márgenes estrechos de las instituciones que históricamente han procurado mantener el control sobre ellas y decidir sobre sus contenidos. Se trata de prácticas y creencias que pueden guardar o no relaciones de continuidad con las grandes tradiciones religiosas, y en especial con el cristianismo, pero que no dependen en primera instancia de mediaciones institucionales; antes bien, estas pasan por la apropiación reflexiva o emotiva de las personas (Hervieu-Léger [1993] 2005). Así, el carácter de estas prácticas y creencias es definido no tanto por principios de autoridad, como solía ser la tónica incluso en la temprana modernidad (1492-1815), sino a partir de criterios cada vez más autónomos y subjetivos (Hervieu-Léger [1993] 2005; Lenoir [2003 ]2005; Beck [2008] 2009). En estas condiciones, se ha abierto todo un horizonte de posibilidades que ha dado lugar, al mismo tiempo, a la emergencia de múltiples y atomizadas formas de vivir la religiosidad.

Por supuesto, en las sociedades aludidas también tienen cabida tanto la incredulidad, la increencia y la indiferencia religiosa, como la creencia apegada a cánones tradicionales de carácter institucional (Greeley 2003), pero, tal y como apunta Frédéric Lenoir en su obra La Metamorfosis de Dios, la tendencia general, al menos en la Europa noroccidental, parece ubicar a las personas en una suerte de punto medio, no siempre fijo ni resuelto, entre la creencia y el escepticismo. Según Lenoir ([2003]2005), ante la tradicional observancia religiosa, se impone hoy en Occidente una actitud de búsqueda espiritual no dogmática que tiende tanto a revitalizar la tradición religiosa judeocristiana como a propiciar la importación/apropiación de espiritualidades foráneas, la mixtura creativa entre elementos religiosos genéticamente disímiles y la transformación paulatina de las representaciones sobre Dios, la espiritualidad y sobre el lugar del ser humano en el universo. Todo lo cual ocurre en medio de ordenamientos político-estatales que, para casi todo efecto prácti$\mathrm{co}$, desde hace décadas operan al margen de la tutela de las religiones institucionalizadas.

Por su parte, América Latina, que es el sitio desde el cual pensamos y escribimos estas líneas, ha visto nacer y crecer durante los últimos setenta años un conjunto de nuevas agrupaciones religiosas que no solamente han ampliado de manera intempestiva la oferta espiritual dentro del subcontinente, sino que, al mismo tiempo, han significado la histórica ruptura del monopolio católico sobre el campo religioso ${ }^{4}$ (Bastian 1997). Hoy día coexisten, en el panorama cultural de la región, viejas y nuevas formas de catolicismo junto con nuevas formas institucionales o semiinstitucionalizadas de cristianismo 
que le han impreso un nuevo y nutrido dinamismo a la vida religiosa de nuestras sociedades.

Movimientos como el evangelismo de orientación pentecostal, de lejos el principal protagonista del proceso anteriormente descrito, se han erigido como una opción real para millones de creyentes de toda la región; en particular para aquellos que forman parte de las capas más empobrecidas de los distintos países que las conforman (Bastian 1997). Los pentecostalismos han sido eficaces, tanto para devaluar los bienes de salvación históricamente producidos por el catolicismo de cristiandad como para capitalizar las insatisfacciones religiosas generadas por estos bienes. Sobre la base de una intensa vida comunitaria, de una lectura literalista de la Biblia y de un fuerte énfasis en las experiencias de tipo emocional, estos han logrado capturar la atención preferente de un importante número de creyentes y de marcar, no obstante, su persistente inferioridad numérica, el carácter actual del campo religioso latinoamericano y caribeño. Cientos de congregaciones pentecostales, de variable tamaño y talante, pueblan nuestros territorios, tanto a nivel rural como urbano, e impactan de particular manera la vida de las poblaciones de nuestro subcontinente.

Si bien el primero de los contextos aludidos parece dar cuenta de un reavivamiento religioso mediante la subjetivación y de la consecuente atomización de las creencias y el segundo de ellos parece hacerlo más bien a través de una pluralización limitada de las opciones religiosas institucionales, lo cierto es que, desde nuestro punto de vista, ambos casos comparten notorios elementos. El proceso de subjetivación de las creencias que hemos descrito como típico de las sociedades europeas noroccidentales no sólo se ha instalado ya entre importantes sectores de la población latinoamericana, sectores para los cuales el creer no pasa entera ni centralmente por la militante observancia religiosa de corte institucional, ${ }^{5}$ sino que, al mismo tiempo, desempeña un papel significativo en las dinámicas competitivas que prevalecen hoy día dentro del campo religioso. Mientras tanto, es claro que en el caso europeo el proceso ha detonado tanto la entrada de nuevas ofertas religiosas con grados variables de formalización institucional, como la vigencia, siquiera débil, de las viejas opciones religiosas. De manera tal que, aún de ese lado del planeta, la pluralización del campo religioso también resulta ser un hecho significativo.

Otra muestra de la persistencia de lo religioso en ambos lados del Atlántico ha sido evidenciada por los intentos de incidencia pública que las organizaciones religiosas continúan protagonizando en el mundo contemporáneo. A partir de una actitud de franca rebeldía ante el modelo liberal que históricamente ha pretendido confinarles al ámbito privado de la vida social y de claro desafío a los regímenes socialistas que han aspirado a su desaparición (Casanova 2012), las instituciones religiosas han desarrollado, a lo largo de la época moderna, toda una compleja y creativa serie de estrategias y mecanismos para mantenerse vigentes en el concierto de las voces públicas (Casanova 1994; Casanova 2013). Se las han ingeniado para recuperar espacios allí en donde los habían perdido, para mantener su influencia allí en don-
5. De acuerdo con datos recogidos por el Pew Research Center (2014) entre octubre del 2013 y febrero del 2014, las poblaciones de los países latinoamericanos y caribeños no sólo han experimentado a lo largo de los últimos decenios una propensión a abandonar las filas del catolicismo para engrosar las del movimiento protestante en alguna de sus múltiples expresiones institucionales (lo que a nuestro juicio es ya indicador de autonomía y de búsqueda espiritual), sino que al mismo tiempo se han visto movidas, en mayor o menor grado según el país, a desafiliarse de cualquier institución religiosa. Los resultados obtenidos son igualmente claros a la hora de mostrar que la asistencia al culto religioso (a misa, etc.) por parte de las personas creyentes tiende a ser poco frecuente en la actualidad; esto aplica sobre todo para aquellas personas que se identificaron como católicas. 
6. El teólogo español Juan José Tamayo (2006) nos recuerda que, durante su pontificado, el papa Juan Pablo II puso en marcha un intensivo y ambicioso proyecto de recristianización o de "segunda evangelización" de Europa, que inició en su natal Polonia, pero que muy pronto se extendió, por intermedio del control doctrinal del cardenal Ratzinger y de la destacada participación de movimientos eclesiales como el Opus Dei, Comunión y Liberación, Legionarios de Cristo, Camino Neocatecumenal y Heraldos del Evangelio a la mayor parte del continente.

7. Esta postura ha sido particularmente popularizada por el papa emérito y cardenal Joseph Ratzinger, para quien la fe católica no sólo constituye el reservorio moral de un mundo fundamentalmente desprovisto de moralidad, sino también el fundamento histórico y trascendental de la razón, del Estado y de la propia convivencia democrática. Véase: Habermas, Jürgen y Joseph Ratzinger. 2008. Entre razón y religión. Dialéctica de la secularización. México: Fondo de Cultura Económica. de recién han empezado a perderla y para hacerse un lugar allí en donde nunca lo habían tenido.

En Europa, por ejemplo, donde el catolicismo perdió hace muchos años la mayor parte de sus prerrogativas públicas, al menos en cuanto aparato gubernamental de Estado, es posible encontrar hoy a la Iglesia católica promoviéndose como la voz crítica de la modernidad capitalista y de sus efectos más perniciosos sobre las sociedades del continente. Asimismo, no es extraño encontrarle impulsando acciones cuyo fin último no sería otro que el de propiciar una recristianización y, en el mejor de los casos, una recatolización del Viejo Continente. ${ }^{6}$ Ella ha procurado mantenerse vigente, por supuesto no siempre con éxito, ya sea presentándose como el contrapeso de la hegemonía secular en el mundo moderno, o bien vendiéndose como la garante del mantenimiento de las raíces cristianas subyacentes a la cultura propia del llamado viejo continente. ${ }^{7}$

De este lado del charco, por su parte, no sólo se constata la perseverancia de la influencia católica en el ámbito de las competencias estatales de tipo gubernamental, sino también el ingreso de nuevas corrientes religiosas de corte institucional en la escena pública; ya sea en tanto agentes en búsqueda de reconocimiento político y cultural o de plano como agentes con pretensiones políticas hegemónicas. Ambas intenciones han estado en la base, por ejemplo, de la formación de partidos políticos de corte evangélico pentecostal en no pocos países del subcontinente desde los años ochenta del siglo XX (Bastian 1999). Estos partidos nacieron con el fin de procurarle al movimiento evangélico un reconocimiento público y estatal similar al históricamente ostentando por la Iglesia católica en muchos de nuestros países, pero también con la clara intención de llevar adelante un proyecto de "colonización" de las instituciones estatales y, a través de él, de los imaginarios compartidos por las poblaciones del subcontinente (Pérez Guadalupe 2017). En última instancia, estas agrupaciones propulsan un proyecto de neo cristiandad, cuyo objetivo no es otro que el de extender los preceptos por los que pretende regirse una parte importante del movimiento evangélico al conjunto de las poblaciones y de las sociedades latinoamericanas.

\section{¿Está agotado el paradigma de la secularización?}

Este escenario de persistencia y aparente reavivamiento de lo religioso, en el mundo occidental contemporáneo, ha suscitado reacciones y explicaciones de la más diversa índole. Entre ellas, no obstante, destacan aquellas posturas que, atónitas ante el fenómeno, se han apresurado a ver en este el síntoma de un reencantamiento global del mundo o, en el caso más extremo, la señal inequívoca de que nuestro mundo moderno nunca fue afectado por un proceso de desencantamiento. Sobre todo en el ámbito académico, tanto en las filas de las humanidades como en la acera de las Ciencias Sociales, desde hace algunos años se han venido acrecentando las voces, entre ellas las 
de estudiosos y estudiosas del fenómeno religioso, que invitan a reconsiderar, y en ocasiones incluso a abandonar, los encuadres hermenéuticos clásicos que tendían a asociar modernidad con secularización y a describir la época corriente en términos del segundo de los factores implicados en dicha asociación (Blancarte Pimentel 2012).

Aunque no dejan de llevar una cuota importante de razón, las posiciones aludidas parten de premisas cuando menos problemáticas y ambiguas de las que merece la pena tomar una distancia prudencial. Estas llevan razón cuando se plantan de manera crítica ante las viejas fórmulas que le atribuían a la modernidad, o a alguno(s) de sus rasgos constitutivos, un efecto absolutamente desintegrador de las expresiones religiosas (idea más ideológica que analítica), pero cometen un error al derivar de esta acertada crítica una desestimación plena de las capacidades heurísticas propias del paradigma de la secularización, tal como bien fue nombrado y descrito por Olivier Tschannen hace ya casi treinta años en un artículo preclaro (Tschannen 1991). En el mismo movimiento en el cual contribuyen a borrar la caricatura en la que tendieron a convertirse las fórmulas que han vinculado modernidad y secularización, estas posturas acaban cayendo víctimas de la misma tendencia. En sus versiones más extremas, no sólo les han cedido a las fórmulas referidas el monopolio sobre la interpretación del carácter de dicha vinculación, sino que al mismo tiempo han acabado haciéndoles el juego. La caricatura que desprecian ha venido a prestarles, al menos en parte, el molde para sus propios diagnósticos.

No deja de ser interesante señalar que aún cuando se ha demostrado en reiteradas ocasiones que el declive de la religión, en tanto prerrequisito de la secularización e indicador de esta, no es ni ha sido nunca el componente central dentro el conjunto de teorías que han tratado de dar cuenta del fenómeno (Tschannen 1991; Casanova 2012), lo cierto y extraño del caso es que es justamente la supuesta no comprobación de esta tendencia la que se ha enarbolado, por extensión, como la prueba por antonomasia de la invalidez del paradigma como un todo. La permanencia de la práctica y de la creencia religiosa tradicional en algunos contextos, así como la emergencia de nuevas prácticas y creencias en otros, se suelen apreciar ya como la falsación de la secularización en tanto herramienta comprensiva y científica, ya como evidencia suficiente de un creciente proceso de des-secularización en las sociedades contemporáneas (Blancarte Pimentel 2012; Casanova 2012). Resulta evidente que esta línea de razonamiento sacrifica, a partir de ciertas expresiones fenomenológicas del comportamiento de lo religioso en el mundo de hoy, todo el potencial heurístico del paradigma.

Lo que suelen olvidar estas posturas, no obstante, es que, dentro del acervo de elementos hermenéuticos brindados por las distintas teorías de la secularización, sobresalen algunos que no sólo permiten superar esta aproximación "fenomenológica" parcial, sino que de forma paralela ofrecen herramientas para comprender, de manera satisfactoria, los fenómenos de los que trata de dar cuenta. Estos elementos de los que hablamos no centran tanto su atención en las manifestaciones puntuales del comportamiento religioso como en 
8. De ahí la importancia de considerar el desarrollo de la modernidad en conjunto (desde sus orígenes hasta la actualidad) y no ya únicamente su comportamiento más tardío o reciente; pues si bien este último período ha dado lugar a una profundización de las transformaciones culturales que fueran detonadas por la temprana modernidad (14921815), lo cierto es que no deja de ser relevante hacer énfasis en el carácter procesual y paulatino de los cambios apuntados. el marco socio-histórico y cultural en el que estos tienen lugar y razón de ser. La mirada que ofrecen es de largo alcance; permiten enmarcar la relación entre modernidad y secularización en el plano de sus grandes condicionantes estructurales. $^{8}$

El más destacado de estos elementos, desde nuestro punto de vista, es aquel que señala no ya el declive de la creencia y de la práctica religiosa en términos generales, sino más bien el de la influencia religiosa en el ámbito global de la organización social. De acuerdo con este enfoque, que se puede encontrar con distintos matices y contrastes en las obras de Max Weber ([1905] 2012), Peter Berger ([1967] 2006), Marcel Gauchet ([1985] 2005), Mariano Corbí (1996; 2007) y, más recientemente, en la del filósofo canadiense Charles Taylor ([2007] 2015), lo que estaría en juego en la noción de secularización referida a la modernidad no es otra cosa más que la actualización última de un proceso histórico de larga data, según el cual lo religioso, en tanto principio instituido e instituyente de lo social y de la realidad del mundo como un todo, habría estado perdiendo de manera paulatina, que no total, su capacidad de totalizar y modelar el ordenamiento de la existencia (las visiones de mundo, etc.).

La modernidad, según estas aproximaciones, habría dado lugar, por primera vez en la historia humana, a la emergencia de sociedades que no tendrían por principal ni más importante factor de organización, conservación o legitimación de los mundos socialmente construidos a referentes, símbolos e imaginarios de índole religiosa (Berger ([1967] 2006). Con variaciones y énfasis diversos, aunque no por completo divergentes, quienes suscriben este enfoque tratan de dar cuenta tanto de los procesos que participaron, de manera sinérgica, en la configuración de las sociedades anteriormente descritas como de las consecuencias socioculturales que un cambio de tal magnitud y significación histórica estaría detonando, o habría detonado ya, en el plano religioso, pero sobre todo en el plano de la estructuración del mundo y en el ámbito de la vida cotidiana de las poblaciones que viven bajo su influjo.

En el primero de los planos, son bien conocidas las tesis que atribuyen la reconfiguración aludida a la emergencia hegemónica de factores estructurales (Casanova 2012), tales como el establecimiento de los Estados modernos, la penetración voraz del capitalismo (sobre todo en su versión industrial) y el creciente desarrollo científico-racional moderno. A cada uno de estos procesos y formas de estructuración social, se les achaca, pensamos que, con suficientes razones de peso, el haber detonado dinámicas de racionalización, no sólo de sus respectivas lógicas de funcionamiento interno sino también una suerte de efecto multiplicador o de contagio (Tschannen 1991; Casanova 2012) sobre otras dinámicas sociales. A ellos se les señala como los causantes de propiciar una racionalización generalizada del mundo, pero también como los precursores de otros procesos subsidiarios que de facto contribuyeron a profundizar dicha tendencia.

La racionalización social, en tanto tendencia de ordenamiento y sistematización autorreferencial de actividades socioculturales específicas (económicas, estatales, gubernamentales políticas, etc.), por razones obvias no solamente 
supuso la expulsión de elementos impertinentes al funcionamiento de las nuevas instancias, sino que de manera concomitante facilitó también la emergencia de esferas especializadas y virtualmente independientes entre sí (Tschannen 1991; Casanova 2012). En el plano religioso, esta re-compartimentalización de la vida social se tradujo, por un lado, en la configuración de una esfera específicamente religiosa, y por el otro, en la autonomización relativa de las nuevas esferas de la realidad respecto de la antigua y omnipresente tutela religiosa.

Aunque esta complejización de la vida social ha solido asociarse de manera preponderante a la aparición de figuras y estructuras propiamente modernas, lo cierto del caso es que para no pocos autores y autoras dichos procesos hunden sus raíces también en desarrollos históricos anteriores a la época corriente. Pensadores como Peter Berger, Marcel Gauchet, Charles Taylor, e incluso el propio Max Weber, de quien muchos derivan los fundamentos generales del paradigma de la secularización, remontan las dinámicas de diferenciación funcional de las esferas sociales (Luhmann [1977] 2009) a períodos y acontecimientos previos a la aparición de la modernidad e invocan condicionantes específicamente religiosos entre los motivos de esta gran transformación. Para Weber, por ejemplo, la racionalización inherente al despliegue del Estado moderno y del capitalismo, había encontrado ya su primer "lugar" de realización en el desarrollo de las llamadas religiones de salvación, pues con su énfasis en los problemas éticos y su propensión a intelectualizar los contenidos de la tradición mítica, estas acabaron provocando tanto una desmagización (desencantamiento) de las imágenes del mundo como el nacimiento de estructuras modernas de consciencia (Mardones 1998).

Esta anotación resulta importante para recuperar el carácter procesual y multifacético implicado en la secularización de las sociedades occidentales, pero también para discernir tanto el verdadero carácter de nuestra época como la extraordinaria peculiaridad que esta reviste dentro del devenir general de la historia humana. Solamente una aproximación de largo alcance temporal y de amplia mirada antropológica puede captar con precisión el lugar que ocupa lo religioso en nuestras sociedades, pues, tal y como bien lo expresa Marcel Gauchet ([1985] 2005), "no existe comprensión posible del fenómeno religioso [contemporáneo] sin la condición de levantar acta de escisión sin apelación que separa el pasado del presente" (12).

Continuando con nuestra argumentación original, es menester que pasemos a indicar ahora algunas de las consecuencias que la diferenciación funcional moderna tuvo en el comportamiento del fenómeno religioso. La primera, y quizás más obvia de ellas, fue la atenuación de su capacidad de estructurar de modo hegemónico el orden general de la existencia. Después de haber estado imbuido en todos y cada uno de los ámbitos de la realidad y de haber modelado buena parte de los valores y significados valederos en ellos, lo religioso instituido empezó a verse recluido en un espacio autónomo y autocontenido dentro del marco de una constelación de esferas sociales igualmente autosuficientes. Con ello, perdió al mismo tiempo su facultad de influir de forma irrestricta en las nuevas esferas especializadas, pero sobre todo sus posi- 
bilidades de ofrecer el soporte pleno para la conservación y la legitimación de los mundos humanamente construidos (Berger [1967] 2006).

Desde esta perspectiva, lo que la racionalización y la diferenciación trajeron consigo fue el quiebre definitivo de las capacidades totalizadoras de lo religioso. Los símbolos, los valores, así como los reservorios de sentido de ascendencia mítico-religiosa que durante siglos constituyeron el soporte estructural más importante de la habitación del mundo occidental (Gauchet [1985]2005), pasaron a ser profundamente socavados y relativizados por el advenimiento de las nuevas lógicas de orientación sociocultural a las que dio origen la modernidad. Ello no sólo trastocó algunas de las funciones históricas más típicas de la religión, sino que de manera paralela dio pie a una multiplicación de los sistemas axiológicos y de las fuentes de sentido (religiosas y no religiosas, claro está). En nuestra era, lo que es valioso y significativo en una esfera, no necesariamente lo es en la otra; aun cuando continúa siendo posible que entre ellas compartan elementos en común y racionalidades afines (Mardones 1998).

La multiplicación aludida detonó una relativización de los esquemas valóricos y en consecuencia una pérdida de plausibilidad sociocultural (Berger [1967] 2006) de los contenidos religiosos. En la modernidad resulta estructuralmente imposible que un solo sistema cultural, y en particular el religioso, garantice un modo de vida (un sistema de valores, un conjunto de reglas o normas) común y obligatorio para todos los miembros de la sociedad. Hoy día los valores, y los contenidos religiosos en general, deben desenvolverse en medio de una situación social que, de manera tendencial, funciona a partir de lógicas seculares. Las personas han incorporado una diversidad, muchas veces contrastante, de racionalidades, y a partir de ello han desarrollado la facultad de problematizar, aunque sea de modo inconsciente, la validez universal o definitiva de cada una de ellas.

El estado de cosas anteriormente descrito no sólo ha provocado una tendencia hacia el descreimiento religioso, como bien podría pensarse, y como de hecho ha sucedido en muchos lugares y países del mundo, sino que, aunque pueda sonar paradójico, ha ocasionado también una creciente pluralización cuantitativa y cualitativa de sus expresiones. Antes que la desaparición de lo religioso, la pérdida de hegemonía religiosa en plano de la organización estructural del mundo ha derivado en su fragmentación y en su multiplicación. Al relativizarse, la práctica y la creencia religiosa han pasado a ser, por primera vez en la historia, un motivo de elección. Aunque nunca en el vacío sociocultural, hoy es lícito, incluso inevitable, elegir qué creer y cómo hacerlo; lo cual a todas luces altera tanto a las condiciones del creer como a las ofertas institucionales que pretenden, aún en nuestros días, fijar y prescribir los contenidos que las creencias podrían o no revestir.

Es fácil apreciar, desde esta perspectiva, que la modernidad no ha llevado irremediablemente (ni tendría por qué llevar en algún momento de la historia) a la supresión absoluta ni de las demandas ni de las necesidades religiosas o espirituales; ella simplemente ha reconfigurado de forma inédita el marco cultural y subjetivo en el que estas tienen lugar (Taylor [2007] 2015). La extraor- 
dinaria particularidad de la época actual queda expresada en la capacidad que hemos desarrollado para convertir en tema de elección aquello que durante miles de años no fue sino un destino incuestionable (Berger 2014). La secularización de las formas matriciales de organización social fue acompañada, como resulta evidente, por un proceso concomitante de secularización de las consciencias, es decir, por un proceso que ha posibilitado la relativización individual de los contenidos religiosos tradicionales y de las formas dogmáticas e inamovibles que estos solían asumir.

\section{Hacia una comprensión cabal del lugar de lo religioso en el mundo contemporáneo}

La persistencia de viejas expresiones religiosas, tanto institucionales como extra-institucionales, así como la explosiva emergencia de nuevas formas de vivir la religiosidad, entendida esta en sentido amplio, pueden interpretarse bien como el resultado de una constante antropológica que haría del ser humano un ser intrínsecamente religioso (Otto [1917] 1996; Eliade [1957] 1998; Luckmann [1967] 1973) o precisamente como una consecuencia de la "orfandad constitutiva" de las sociedades modernas. ${ }^{9}$ Privadas de estructuras axiológicas y de sentido totalizantes e inequívocas, nuestras sociedades han dado pie, por extraño que esto pueda resultar, a la intensificación de las demandas de sentido, y en el mismo movimiento, le han garantizado un lugar de privilegio a las "reservas de sentido" canalizadas por instituciones o por referentes de tipo de religioso (Berger y Luckmann [1995] 1997). A fin de cuentas, muchas personas y grupos de personas tratan de encontrar el remedio a la enfermedad en la enfermedad misma, pues procuran salir del desamparo existencial que les vino dado por la desestructuración religiosa del edificio del mundo, ya sea en los restos que esta dejó tras de sí, o bien, en la invención no necesariamente consciente de nuevas o renovadas formas de religiosidad (Hervieu-Léger [1993] 2005).

Los referentes religiosos no sólo continúan brindando hoy, como siempre lo hicieron, respuestas a las preguntas últimas de la existencia o aportando herramientas para enfrentar las "situaciones marginales" consustanciales a la vida humana y social (la muerte, el dolor, el mal, la injusticia, etc.), sino que al mismo tiempo han venido a ofrecer medios efectivos para hacer frente, siquiera por medio de la negación parcial, tanto a las consecuencias no deseadas de la modernidad de signo capitalista como a la excesiva racionalización técnico-científica y burocrática del mundo a la que esta ha dado lugar. Las expresiones religiosas de viejo y nuevo cuño han logrado reinventarse justamente en los intersticios de la modernidad, es decir, allí en donde esta no ha estado a la altura de sus propias promesas emancipatorias, o bien, allí en donde esta no ha sido capaz de ofrecer respuestas satisfactorias a las demandas de sentido o de significación existencial que hacen o han hecho parte intrínseca de la experiencia humana conocida (Luckmann [1967] 1973).

9. Afirmar que la religiosidad es una constante antropológica por supuesto no nos da licencia para tomar por verdaderas las realidades supraempíricas a las que suelen referirse las distintas religiones institucionalizadas. Dicha afirmación únicamente es capaz de hablarnos acerca de una propensión que ha acompañado al ser humano prácticamente desde los orígenes de la especie. Si esta hunde sus raíces en la propia estructura psíquica del sujeto (Jung; Eliade), en el miedo y la imaginación (Spinoza), o en la alienación (Feuerbach; Marx),

es un asunto que sin duda sigue siendo objeto de múltiples polémicas e interpretaciones. 
Por más irónico que esto pueda parecernos, la misma fuerza histórica y cultural que provocó la racionalización y la consecuente diferenciación funcional de la realidad socialmente construida, así como la pérdida de capacidad englobante de lo religioso, denotó el surgimiento de condiciones favorables a la proliferación de nuevas expresiones religiosas.

En este sentido, la secularización no sería, como bien lo han sustentado cientistas sociales de la trayectoria y talla de Daniéle Hervieu-Léger ([1993] 2005) o de Peter Berger (2014), ya el proceso que ha llevado o tendría que llevar inexorablemente a la desaparición de lo religioso en nuestras sociedades, sino más bien una tendencia de gran calado societal que habría propiciado o estaría propiciando aún importantes reconfiguraciones, tanto en los contenidos de las creencias y de las prácticas religiosas como en las propias estructuras del creer (Hervieu-Léger [1993] 2005). Si bien la diferenciación funcional de las esferas sociales propiciada por la modernidad en efecto minó la capacidad que en otros tiempos tuviera lo religioso para estructurar u organizar globalmente tanto la realidad como los universos humanos de significación, lo cierto es que esta no cortó de raíz ni nuestra propensión antropológica a encontrarle sentido a la existencia más allá de sí misma (Berger y Luckmann [1995] 1997), ni nuestra inclinación a dotárselo a través de la propia acción humana. En palabras de Hervieu-Léger ([1993] 2005):

La modernidad rompe con lo sagrado en tanto devuelve a los hombres y a sus capacidades la preocupación por racionalizar el mundo en el que viven y de controlar, a través del pensamiento y la acción, las tendencias al caos. Sin embargo, la necesidad fundamental de conjugar la incertidumbre estructural de la condición humana no desaparece por el mero hecho de que las «cosmizaciones sagradas» (Berger) se desvirtúen debido al proceso de racionalización. Tampoco subsiste como el remanente de un universo sacro convertido en obsoleto. Resurge de la propia modernidad y se redistribuye en una multiplicidad de demandas de sentido aún más exigentes, pues ya no se trata de pensar su lugar en un mundo estable, sino de situarse en un espacio social abierto en el cual el cambio y la innovación son la norma. (...) La modernidad provoca, pues, que de múltiples maneras recobre actualidad la cuestión del sentido y las diversas expresiones de la protesta contra el no-sentido que le corresponden (124-125). 
Para valernos de una metáfora, podríamos decir que la modernidad detonó la explosión de lo religioso en tanto fuente englobante de sentido y dio pie, al mismo tiempo, a la aparición no sólo de una cierta desolación existencial, sino también a la emergencia de una multiplicación sin precedentes de las fuentes de sentido a disposición de los colectivos humanos; fuentes que, en muchos casos, tardaron décadas en aparecer y que en buena medida continúan configurándose hasta el día de hoy. Se trata, por supuesto, de un proceso que fue y ha sido al mismo tiempo alimentado por la pluralización de formas de vida que ha tenido lugar de manera ininterrumpida en nuestras sociedades, así como por el choque cognitivo que esta diversificación, originada en gran medida gracias a la propia secularización, ha provocado en muchas personas y grupos sociales a lo largo y ancho de todo el orbe. ${ }^{10}$ Esta pluralización de las formas de vida ha provocado una multiplicación de las opciones de vida (a nivel axiológico, moral e intelectual) a disposición de las personas y ha significado de manera correlativa la relativización de todo aquello que, en un momento de nuestra historia, simplemente podía darse por descontado. Resulta a nuestro juicio evidente que dicho proceso ha traído consigo efectos positivos para la libertad y la autonomía humanas, pero también ha tendido a generar una extendida ansiedad ontológica entre amplios sectores de la sociedad; así, mientras algunas personas experimentan la relativización como algo positivo para sus vidas, otras tantas lo viven más bien como una pesada e indeseable carga (Berger y Luckmann [1995] 1997; Berger 2014), es decir, como una fuerte amenaza para su estabilidad psicológica o cognitiva.

En virtud de lo expuesto, estamos ahora en mejor capacidad de comprender el porqué de la persistencia y/o de la vitalidad de las manifestaciones religiosas en las sociedades occidentales contemporáneas. Aunque la modernidad ha tornado imposible que lo religioso constituya en estas, como lo hiciera en el pasado, el fundamento último de la realidad y de los ordenamientos sociales, ella misma le ha asegurado, quizás a pesar de su propia autocomprensión, un papel relevante en la vida de los colectivos humanos. Después de haber sido despojada de muchas de sus funciones y prerrogativas, la religión sigue presentándose hoy como una importante fuente de sentido; ciertamente, no ya como una fuente totalizante, pero sí como un destacado acervo intermedio a disposición de las personas. Se trata, claro está, de una opción entre otras tantas posibles, pues como bien cabe recordar, existe hoy día una cantidad cada vez mayor de personas que viven o procuran vivir su vida al margen de cualquier referente de carácter transcendental o religioso, y que de hecho encuentran sentido en prácticas, creencias e instituciones enteramente laicas (Berger 2014), mas ello no borra que la religión, en sus múltiples expresiones, sea aún en nuestros días quizás el más potente reservorio de sentido disponible dentro del espacio social.

Entender la secularización, desde esta perspectiva, fácilmente puede hacernos ver que no existe una verdadera contradicción entre las tesis que defienden el carácter eminentemente secular de nuestra era (Taylor [2007] 2015) y aquellas que resaltan más bien la persistencia actual de las manifestaciones
10. Volvemos a hacer referencia al orbe entero, pues, aunque como lo hemos dicho nuestro foco de atención está puesto primordialmente en las sociedades del mundo (latino)americano y europeo, lo cierto es que tanto la modernidad como la secularización por ella vehiculizada han tenido repercusiones en todas las culturas del planeta. Ello ha resultado así por el talante globalizador (imperialista y colonialista) que, desde sus tempranos inicios ha tenido el moderno sistema-mundo capitalista, pero también por la hegemonía cultural que los países centrales han logrado alcanzar dentro de él. Respecto de este último tópico, pueden consultarse los capítulos XVI, XVIII y XX de Dussel, Enrique. 2001. Hacia una filosofía política crítica. Bilbao: Editorial Desclée De Brouwer. 
religiosas; nos ayuda incluso a procesar y a dar cuenta de ese fenómeno sociocultural a veces tan desconcertante al que, de manera no siempre atinada, etiquetamos con el nombre de fundamentalismo religioso. Lejos de ver en las expresiones fundamentalistas de tipo religioso un mero resabio de tiempos pre-modernos o una vuelta a estos, tal forma de encuadrar la secularización y sus efectos sociales nos ofrece la posibilidad de caracterizarle más bien como una especie de intento desesperado por encontrar certezas existenciales inequívocas allí en donde estas se han perdido, o bien como un tipo de proyecto abocado a la reconstitución de reservas de sentido de carácter omnicomprensivo y universalmente vinculantes (Berger y Luckmann [1995] 1997). En el fondo, se trata de una reacción negativa y radical, tanto a los innegables desplazamientos que ha sufrido lo religioso en la modernidad (Armstrong [2000] 2017) como a la inevitable relativización axiológica y moral que ha venido aparejada a dichos desplazamientos, por un lado, y a la pluralización de las formas u opciones de vida que son parte inherente de nuestras sociedades, por el otro. Aun cuando sea el fundamentalismo un fenómeno eminentemente moderno (Armstrong [2000] 2017), este no ha tenido ni tiene reparo alguno en comportarse como una fuerza disruptiva de la modernidad misma. Tal como bien lo apunta el teólogo Juan José Tamayo, el fundamentalismo:

(...) adopta una actitud hostil frente a los fenómenos socio-culturales de la modernidad que, a su juicio, socavan los fundamentos del sistema de creencias: la secularización, la teoría evolucionista, el progresismo, el diálogo con la cultura moderna y posmoderna, las opciones políticas revolucionarias de las personas y de los grupos creyentes, la emancipación de la mujer, los descubrimientos científicos, los avances en la genética, los movimientos sociales, los métodos histórico-críticos, etc. Todos ellos son considerados enemigos de la religión y en esa medida son combatidos frontalmente (Tamayo Acosta 2004, 94).

Mal haríamos, sin embargo, en caracterizar estas tendencias y actitudes como los rasgos dominantes de nuestras culturas. Dada la altisonancia y la beligerancia de este tipo de movimientos, muchas personas y analistas sociales han llegado a sentir la propensión de observar en ellos los signos de un supuesto agotamiento de la secularización, como lo hemos discutido ya a lo largo del artículo, pero también los de un todavía más cuestionable retorno a tiempos en los que la religión o los imaginarios y símbolos de tipo religioso tenían la capacidad de englobar al conjunto entero de la sociedad y de las 
instituciones sociales. Cuando la realidad del caso, desde nuestro punto de vista, es que estos movimientos más bien constituyen buenos indicadores del carácter secular y plural de nuestros ordenamientos socioculturales. No ya porque sean portadores positivos de dichos valores, sino más bien porque su proyecto es una reacción en contra de ellos; una reacción en contra de una sociedad que perciben cada vez más alejada de Dios y de la segura moralidad monista religiosa o tradicional. Lejos de ser meros resabios del pasado, los proyectos fundamentalistas son reveladores de los profundos vacíos existenciales o de sentido que son constantemente (re)producidos por la modernidad, así como de la muy especial incapacidad que tienen algunos sectores sociales, no siempre fijos sino más bien móviles, de lidiar con dichos vacíos. ${ }^{11}$

El fundamentalismo es, desde esta perspectiva, un proyecto claramente abocado a la eliminación del relativismo y a la restitución, en condiciones modernas, de las poderosas certezas morales y existenciales que supuestamente tenían lugar en las sociedades pre-modernas (Berger 2014). La mayor limitación que deben enfrentar quienes protagonizan los impulsos fundamentalistas, sin embargo, es el hecho de tener que desarrollar su proyecto en medio de condiciones sociales que no solamente no controlan en todos sus extremos, sino que en muchos sentidos se encuentran cada vez más alejadas de sus particulares idearios de vida. En el límite, el proyecto fundamentalista tendría que extirpar tanto el pluralismo que se ha abierto paso a modo de dato fáctico en nuestras sociedades como los condicionantes culturales, políticos, legales e institucionales que hoy día tienden a originarle y respaldarle (como tendencia) en mayor o menor grado; lo cual, como bien puede colegirse, es a todas luces un proyecto de difícil realización. El proyecto resulta complicado de sobrellevar aún para aquellas personas que de forma relativamente voluntaria han decidido orientar sus vidas a partir de principios fundamentalistas, pues es evidente que su opción de vida, por más sectaria o autocontenida que se presente o exprese, no tiene la capacidad de protegerles por completo ni del influjo pluralista ni tampoco de la duda que acompaña como tendencia a toda forma de creer (o no creer) en las sociedades occidentales (Berger 2014).

Si bien es cierto el fenómeno del fundamentalismo, por su propia beligerancia y extremismo, tiende a destacar de modo particular en nuestras sociedades, lo cierto del caso es que este no puede tomarse ni como una tendencia necesariamente mayoritaria, ni mucho menos como la medida a través de la cual tendríamos que evaluar la totalidad de las creencias y de las prácticas religiosas que circulan dentro del espacio social o las estructuras del creer individuales o colectivas que sustentarían hoy dichas prácticas y creencias. Salvo algunas raras excepciones, los y las habitantes de las sociedades occidentales tienden a ubicarse más bien en puntos intermedios entre las salidas relativistas y las fundamentalistas (Berger 2014). Una importante cantidad de personas continúan reproduciendo, creativa o inercialmente, muchos de los contenidos vehiculizados por las viejas opciones religiosas, sin necesariamente llegar a sentirse poseedoras de una verdad absoluta, mientras que otras personas tienden a abrazar, de forma quizás aún más autónoma, nuevas opcio-
11. Si bien el término "fundamentalismo" nace para nominar a un particular movimiento religioso de orientación conservadora surgido a principios del siglo XX en el seno del campo evangélico estadounidense, es ya bastante claro que en el presente artículo le estamos utilizando más bien para

describir aquella actitud social, grupal o individual que no solamente reacciona con especial malestar ante el pluralismo axiológico-moral propio de las sociedades modernas, sino que al mismo tiempo propone vías para suprimirlo. Las personas 0 agrupaciones que le reproducen suelen quererse poseedoras de verdades, dogmas y valores infalibles y extensibles, de forma cuasi obligatoria, al conjunto de la sociedad. 
12. Hasta el momento hemos estado desarrollando nuestras reflexiones sobre la base del comportamiento general de las sociedades occidentales; $\sin$ embargo, aunque pueda resultar una obviedad, es menester señalar que las tendencias reseñadas no suelen manifestarse de igual forma en cada una de las regiones y naciones que integran el mundo occidental. Tal como procuramos evidenciarlo más adelante, la intensidad de las demandas de sentido tiende a ser mayor sobre todo en aquellos contextos en los que priman la inseguridad existencial, las carencias materiales, la desprotección jurídica y las desigualdades socioculturales. nes religiosas de carácter institucional o extra-institucional que poco o nada tienen que ver ya con la promoción de dogmas inamovibles o de pretensiones totalitarias; tendencias que, por supuesto, variarán en función de las particularidades de los distintos contextos sociales, políticos y económicos susceptibles de ser analizados. ${ }^{12}$

\section{El fundamentalismo como amenaza para el pluralismo y la convivencia}

El hecho de que no podamos tomar al fundamentalismo como la medida de toda creencia religiosa y de toda forma de creer en las sociedades contemporáneas, tampoco nos da licencia para menospreciar ni para soslayar la absoluta relevancia social que hoy día reviste el fenómeno. Aun cuando este no es necesariamente la tendencia dominante en cada uno de los diferentes lugares (países, regiones) que conforman el mundo occidental, la realidad es que tanto su ideario intransigente como su propensión impositiva constituyen serias amenazas para la convivencia sociocultural y para la reproducción o la profundización de las bases político-institucionales de tipo democrático y republicado sobre las cuales han aspirado levantarse, con mayor menor grado de éxito y ahínco, las naciones occidentales durante los últimos doscientos años. Su profunda aversión a la incertidumbre, al relativismo y al pluralismo no solamente ha colocado a los fundamentalismos en una posición de rechazo al cambio sociocultural (o por lo menos de rechazo al cambio que perciben como moralmente peligroso o amenazante), sino que de hecho suele motivarles a emprender acciones combativas en contra del avance o la profundización de dicho cambio. Las personas inmersas en este particular imaginario albergan, en el fondo, la ilusión de poder restituir, mediante su accionar, tanto los principios morales inequívocos que supuestamente existieron alguna vez en nuestros universos sociales, como las grandes y potencialmente totalizadoras fuentes de sentido propias de las sociedades pre-modernas (Berger 2014).

Si bien nuestra opinión particular, por supuesto debatible, es que un proyecto de dichas dimensiones se encuentra irremediablemente condenado al fracaso, lo cierto del caso es que, como toda aspiración que es creída como posible, la actitud fundamentalista no deja de tener incidencia real, muchas veces efectiva, en la dinámica concreta (sociopolítica, jurídica y cultural) de nuestras sociedades. En la medida en que la crítica fundamentalista a la modernidad no se contenta (solamente) con proponer una actitud de fuga sectaria como remedio a los problemas morales por ella detectados, sino que más bien propone una misión reformadora de pretensiones y alcances globales, es inevitable que ella entre en conflicto directo, tanto con los contornos básicos de los ordenamientos modernos como con aquellos modos de vida y sectores sociales que mejor encarnan la pluralización axiológica y moral, la cual suele estar asociada a dichos ordenamientos. 
El proyecto, casi como norma, tiende a oscilar entre las actitudes de retaguardia y las de vanguardia, ya que por un lado suele manifestarse reactivamente a través de una férrea oposición a cualquier cambio social (jurídico, institucional) que tenga por norte u objetivo el reconocimiento del creciente pluralismo moral que atraviesa nuestras sociedades, mientras que, por el otro, asume una clara intención de reconformar el carácter general de la vida social a partir de la extensión de sus propios preceptos e imaginarios al conjunto de la población. Este último ha sido el caso, por ejemplo, de los Partidos o movimientos políticos de orientación evangélica (pentecostal o neopentecostal) que, desde los tempranos años ochenta del siglo pasado, se han estado abriendo espacio en los campos político-electorales de la mayor parte de los países latinoamericanos (Bastian 1999) y que han logrado acceder ya a importantes puestos de poder o de decisión dentro de la institucionalidad pública-estatal de nuestra región (Pérez Guadalupe 2017).

Resulta evidente que, por tratarse en primera instancia de fenómenos típicamente reactivos, los distintos fundamentalismos presentes en nuestras sociedades han tendido a manifestarse con más beligerancia, sobre todo allí en donde los cambios socioculturales y las reivindicaciones de cambio han tenido calado efectivo o luchan por tenerlo. Aunque suene casi obvio, las sociedades menos dadas a la transformación presentan, al mismo tiempo, condiciones menos favorables para la aparición de proyectos de orientación fundamentalista; no ya necesariamente porque sean estas sociedades dechados de apertura o tolerancia, sino más bien porque en ellas el statu quo se encuentra poco amenazado. Es difícil, sin embargo, encontrar hoy un solo país que no esté siendo atravesado por distintos procesos de transformación y de pugna sociocultural. Los países que no están experimentando transformaciones en el ámbito específicamente religioso, las están viviendo en los modos de asumir e interpretar los roles y las identidades de género, en las maneras de vivir y entender la sexualidad y, por supuesto, en las distintas formas que desde hace años viene asumiendo la institución familiar en la mayor parte de las naciones occidentales.

Destacamos estas últimas transformaciones o fuentes de cambio sociocultural, entre otras tantas que podríamos mencionar, no sólo por la gran notoriedad y significación política que han adquirido durante los últimos cincuenta años, sino sobre todo porque son justamente ellas las que han tendido a recibir, sin lugar a dudas, un mayor rechazo activo de parte de los movimientos fundamentalistas (Vaggione 2013). En el caso latinoamericano, que es el caso que conocemos con mayor propiedad, no hace falta repasar mucha bibliografía y documentación histórica para descubrir que las distintas formas de fundamentalismo que recorren o han recorrido nuestros escenarios sociopolíticos surgieron en gran medida como reacción no ya al pluralismo cultural en conjunto, sino más bien a las crecientes reivindicaciones propulsadas por los movimientos feministas y de la diversidad sexual. Han sido las exigencias político-culturales (jurídicas, etc.) de dichos movimientos las que, con su justo cuestionamiento al statu quo patriarcal y heteronormativo, más frecuente- 
mente han motivado las reacciones fundamentalistas (Arguedas Ramírez 2010; Sagot Rodríguez 2012; Vaggione 2013).

Nuevas y viejas instituciones religiosas han visto en estas exigencias ( $y$ en las personas que las enarbolan) una amenaza para su poder religioso, en gran medida sustentado en antiguos andamiajes patriarcales, pero sobre todo han solido ver en ellas el signo por antonomasia de la decadencia moral de nuestras sociedades. Sobre la base de una interpretación dogmática o literal de las escrituras bíblicas (o de su propio corpus doctrinal), condenan de manera militante, tanto las mencionadas reivindicaciones como los modos de vida o las opciones vitales que están detrás de su formulación. Para estos movimientos, católicos y evangélicos en su mayoría, adversar el progreso de la plena igualdad de género, del reconocimiento jurídico de los derechos sexuales y reproductivos, así como de la legitimación de las prácticas y de las identidades sexuales no-heteronormativizadas representa por supuesto un asunto de poder, pero en el límite, también, una forma de detener la propagación del "pecado" y de la "decadencia moral" en el mundo.

Podemos afirmar, a la luz de lo comentado en las líneas anteriores, que la politización contemporánea de la sexualidad (quizás menos reciente de lo que se piensa) ha abierto a su paso, al menos en los países latinoamericanos, no una (re)politización de lo religioso (como si las expresiones religiosas recién hubiesen adquirido su estatus político o alguna vez hubiesen dejado de tenerlo), sino más bien una suerte de reconfiguración de los espacios y de los canales a través de los que estas expresiones se manifiestan; lo cual, efectivamente, pone en riesgo tanto las posibilidades de avance de las demandas impulsadas por los feminismos y por los movimientos de la diversidad sexual como a los intentos prescriptivos (políticos por donde se les mire) que han intentado y siguen intentando hoy mantener alejada a la religión de los ámbitos de decisión político-estatales o, más aún, de la esfera pública. Viejas y ya de por sí politizadas instituciones religiosas como la Iglesia católica que, en sentido estricto, nunca perdió del todo sus capacidades de influir en el terreno estatal de países de la región, se las han arreglado, como ya lo indicamos más arriba, para mantener o para reconstruir su lugar dentro de la vida social; mientras que "nuevas" expresiones institucionales, como los pentecostalismos de distinto signo que integran los campos religiosos latinoamericanos desde hace algunos decenios, han procurado ingresar, no siempre con éxito, a ámbitos de incidencia política que hasta hace no mucho tiempo les eran indiferentes o simplemente les resultaban de difícil de acceso (Pérez Guadalupe, 2017); con lo que se reafirma, entre otras cosas, que las expresiones religiosas de corte institucional de la región ni están próximas a morir, ni tampoco están dispuestas a recluirse en su terreno primario de acción (tampoco tendrían por qué hacerlo, en sentido estricto).

Aunque dudosamente novedosos, son este tipo de fenómenos los que suelen encender, por supuesto no sin razones, las luces de alarma de los y las activistas de los Derechos Humanos y los que hacen a muchos académicos y académicas dudar (incluso renegar) hoy, como lo hemos discutido a lo largo de todo el artículo, de las potencialidades heurísticas del paradigma de la se- 
cularización. No obstante, cabe señalar, como también lo hemos argumentado con amplitud desde el inicio del escrito, que estas reacciones, fundamentadas en gran parte, suelen partir no de lo que los procesos de secularización realmente han provocado en las sociedades modernas, sino más bien de lo que suponen tendrían que haber provocado a estas alturas de la historia. Si bien no vemos como reprochable el que se espere que lo religioso no interfiera negativamente en el reconocimiento pleno de la diversidad y de la libertad humanas o que se espere que al menos no lo haga valiéndose de la institucionalidad estatal, pues ello representa una condición necesaria para la convivencia, lo cierto es que también debemos reconocer que esto no es algo que podría exigírsele a la secularización ni siquiera allí en donde ha tenido mayor calado. La secularización, antes que una medida normativa abocada a la desaparición de lo religioso, es un proceso diferenciador de las esferas sociales y de pluralización axiológica; aunque por un lado contribuye a relativizar el peso o el lugar social de las expresiones religiosas, nada en él hace que estas abandonen de forma automática sus intenciones totalizantes o sus anhelos de protagonismo, muy por el contrario, puede contribuir más bien a reavivarlas.

Más allá del peligro que puedan o no correr hoy los procesos de secularización, que como ha quedado claro son difícilmente reversibles, las que indudablemente se encuentran sometidas a un fuerte asedio son las medidas normativas que históricamente han tratado de limitar al mínimo la influencia política de las instituciones y de las ideas de raigambre religiosa en nuestros países. Es justamente la laicidad, en tanto solución jurídica-institucional para contener los impulsos totalizadores de algunas expresiones religiosas, la que se ha visto mayormente afectada por los más recientes intentos religiosos de utilizar la política y la institucionalidad estatal como plataformas de lucha e incidencia social (Blancarte 2015). Amparadas en una larga trayectoria de imbricación con los poderes políticos civiles, y animadas por una actitud eminentemente colonizadora, las instituciones cristianas suelen tener una gran propensión a "invadir" de manera constante el ámbito propiamente estatal (incluso allí en donde se les había apartado de este), así como una fuerte disposición a mantener una voz audible y destacada dentro del coro de las voces públicas (Casanova 1994); lo cual, sin duda alguna, hace que la autonomía estatal, que también forma parte de los procesos de secularización, se vea expuesta a múltiples influencias religiosas y a constantes arremetidas que ponen en jaque su lógica autonómica de funcionamiento. Aunque ciertamente tienen algún tipo de relación, es claro ahora que no conviene que confundamos, para efectos analíticos, pero también políticos, los procesos de secularización con las dinámicas de laicización, pues como bien lo apunta Roberto Blancarte (2015):

\section{(...) mientras la secularización se relaciona con el proce-}

so general de diferenciación social, la laicidad se relacio-

na con el trabajo permanente de negociación entre la es-

fera de lo político (donde predomina el Estado) y la esfera 
de lo religioso. Este proceso permanente de negociación y renegociación sucede en el espacio creado por la intersección entre las esferas política y religiosa, y no es incongruente con el creciente trabajo de secularización avanzado por otras esferas, particularmente la del mercado (la economía). De la misma manera que pueden moverse incluso en sentido contrario: sociedades más secularizadas pueden conocer retrocesos en sus procesos de laicización, o viceversa (670).

Este proceso permanente de negociación y renegociación que sucede entre las esferas política y religiosa es, a nuestro modo de ver, de hecho, provocado por la secularización misma, pues en la medida en la que esta ha empujado hacia una transformación del lugar ocupado por lo religioso en los ordenamientos y en los imaginarios sociales, ha fomentado al mismo tiempo que las instituciones religiosas y las personas o agrupaciones creyentes asuman una actitud de reconquista de los terreros perdidos. Ante la notoria primacía de la lógica estatal o de la razón de Estado dentro del ámbito político, las expresiones religiosas han tratado de idear toda una serie de alternativas o mecanismos tendientes a evitar que los símbolos e imaginarios que promulgan pierdan toda capacidad de comunicación social y de incidencia en la conformación de los destinos socialmente compartidos. La gran particularidad de esta situación reside en que las instituciones religiosas ya no tienen la posibilidad de dictar las reglas del juego, sino que son, quizás por primera vez en la historia occidental, un participante más de este. No deja de ser ilustrativo, en tal sentido, el hecho de que la Iglesia católica en muchos de nuestros países latinoamericanos recurra hoy a estrategias de incidencia política que no pasan ya únicamente por el plano estatal, en donde ha sido despojada de muchas de sus antiguas prerrogativas, sino más bien por la presión civil o por la participación en el juego de democrático (Vaggione 2009), o bien el hecho de que fracciones del movimiento evangélico latinoamericano hayan decidido, desde hace más de treinta años, crear partidos políticos con el fin de contrarrestar el avance del secularismo, de la laicidad y del reconocimiento de derechos sexuales (Pérez Guadalupe 2017).

El gran reto que enfrentan hoy los movimientos sociopolíticos que luchan por el reconocimiento pleno de los Derechos Humanos y por la profundización de la autonomía individual no es el de la supuesta desecularización de las sociedades modernas, sino más bien el hecho de que ni las instituciones ni las creencias religiosas difícilmente se contentarán, en algún momento de la historia, con ocupar un lugar marginal dentro del conjunto de la vida social. En la medida en que se mantengan como fuentes de sentido e identidad, estas serán importantes movilizadoras de la acción social y, por tanto, también de la acción política (Panotto 2017); lo cual inevitablemente debe llevarnos a pre- 
ver que ninguna solución institucional abocada a la laicidad, por más sofisticada que sea, podrá detener por completo los afanes de la incidencia política que son albergadas por muchas instituciones religiosas y que son consustanciales a lo religioso mismo.

\section{Los límites de la laicidad: comprendiendo al "otro fundamentalista"}

Resulta perfectamente comprensible y justificable, no obstante, que en las sociedades que hoy se encuentran amenazadas por el fenómeno fundamentalista, en cualquiera de sus múltiples manifestaciones, cada vez sean más fuertes las voces de aquellos grupos y sectores que, desde hace años, han estado reclamando una mayor separación entre los asuntos políticos de interés común y los asuntos religiosos. Cabe recordar que, en Latinoamérica y el Caribe, tanto los aparatos estatales como los grupos políticos que les han dirigido hasta la actualidad han sido bastante proclives a dejarse permear por influencias religiosas de la más diversa índole (Fuentes Belgrave 2014); se trata esta de una herencia colonial que no logró romperse por completo ni con el advenimiento de las independencias, ni con el ascenso hegemónico de nuestra singular modernidad, ni tampoco con los esfuerzos deliberados que, en distintos momentos de la historia de la región, fueron acometidos con el fin de limitar el influjo religioso (sobre todo de signo católico) en los asuntos público-estatales.

El ascenso de los fundamentalismos religiosos, en concomitancia con la penetración cada vez más evidente e inevitable del pluralismo axiológico en nuestras sociedades, por supuesto no sólo ha provocado un reavivamiento de los viejos reclamos que desde el siglo XIX han estado bregando con toda justicia por la separación efectiva entre la Iglesia católica y el Estado, sino que al mismo tiempo han alimentado demandas que van mucho más allá de esta primera exigencia. Lo que muchos movimientos, grupos y sectores piden hoy en América Latina es que se establezcan barreras jurídico-administrativas que delimiten y separen con toda claridad el ámbito público-estatal y el ámbito religioso. Casi como remedio mágico, defienden esta vía como una forma de mantener alejadas a las agrupaciones religiosas del plano estatal y como una manera de contrarrestar, cuasi de forma definitiva, sus ímpetus políticos; postura que a todas luces tiene como sustento no una interpretación fehaciente del fenómeno religioso, sino más bien un proyecto de corte normativo que a la larga podría llevarle a obviar sus propias limitaciones.

Si bien estamos firmemente convencidos de que la instauración de una laicidad efectiva es condición necesaria para el avance del reconocimiento pleno de los Derechos Humanos y de las reivindicaciones identitarias transgresoras del orden establecido, lo cierto es que también creemos prudente, incluso como principio para garantizar el logro de los objetivos perseguidos, advertir que por sí misma la laicidad, entendida como la mera separación entre las re- 
ligiones institucionalizadas y el Estado o como el total alejamiento de referentes religiosos de la esfera pública, no sólo podría llegar a ser insuficiente para alcanzar los propósitos, sino que, llevada hasta sus límites, incluso sería contraproducente. Posiblemente se perdería sobre todo allí en donde cree ver en arreglos institucionales tales como la necesaria separación entre las religiones institucionalizadas y el Estado o la prohibición del uso de motivos religiosos en las luchas político-electorales, la solución para que lo religioso deje de ser un movilizador político y para que las organizaciones o las personas creyentes abandonen sus intenciones de incidir en el devenir de nuestras sociedades más allá de sus propios ámbitos eclesiales. Sería un grave error analítico (también táctico) derivar de estas medidas la despolitización de lo religioso o su privatización (Casanova 2012).

Tal como bien lo ha advertido el filósofo Charles Taylor (2011), la laicidad, antes que un mero arreglo jurídico, lo que busca esencialmente es crear las condiciones necesarias para que las sociedades logren incorporar dentro de sí principios elementales de convivencia y cordialidad entre los distintos. De acuerdo con su parecer, esta tendría que definirse no tanto por las concreciones institucionales específicas que cada sociedad le dé o le ha dado históricamente a dicho ideal, sino más bien por las metas que podrían derivar de él. Lo mínimo que cabría esperar de un ordenamiento social de tipo laico, según Taylor (2011), es que nadie sea perseguido por sus creencias básicas (religiosas o no religiosas) u obligado a suscribir prácticas o creencias que no comparte, que exista plena igualdad jurídica entre las personas con distintas creencias y que todas las corrientes espirituales y/o de pensamiento puedan participar del proceso constante a través del cual la sociedad "determina qué metas se propone (identidad política) y cómo alcanzarlas (el concreto régimen de derechos y privilegios)" (2011, 40). Aunque no siempre fácil de asimilar, esta última meta resulta fundamental en cualquier sociedad que se precie de ser democrática y es justamente la que tendría que tenerse en consideración a la hora de ponderar la proporcionalidad de los límites que muchas veces se tratan de establecer entre la política y la religión.

Entre los grandes errores que suelen reproducir los colectivos y quienes promueven la laicidad como solución al no reconocimiento de los Derechos Humanos o de las identidades históricamente relegadas, ciertamente está, como ya lo indicamos más arriba, el de creer que con la separación formal entre las instituciones religiosas y el Estado automáticamente se desactivarán los ímpetus políticos de lo religioso (en tanto voluntad y capacidad de incidir en la conformación de los destinos compartidos), pero también se encuentra el de menospreciar las calidades ciudadanas de las personas que basan buena parte de su accionar en este mundo en orientaciones religiosas. Aun cuando sea sano y factible, para efectos de la preservación o instauración de las metas de libertad e igualdad, mantener separados los asuntos estatales de los intereses religiosos de corte institucional, tendríamos que preguntarnos si es igualmente correcto impedir que las organizaciones civiles de carácter religioso (y las personas creyentes) participen, como un agente más, del juego democrático o de las discusiones públicas de interés general desde 
sus respectivos marcos de interpretación del mundo, pues finalmente un impedimento tal no solamente podría ir en contra de los cimientos mismos de la democracia, sino también en contra del ideal de convivencia que estaría en el horizonte utópico de cualquier proyecto político-cultural de inspiración laica.

Además de antidemocráticas e ingenuas, las posturas que estarían cómodas con excluir a las expresiones religiosas de la esfera pública corren el serio peligro de estar alimentando una poco deseable línea de separación radical entre sectores sociales. Por un lado, estarían los sectores ilustrados, creyentes o no creyentes, pero cognitivamente capaces, en todo caso, de establecer las distancias de rigor entre lo público y lo privado, y por el otro estarían los sectores oscurantistas, que, en lo esencial, se distinguirían por su flagrante incapacidad de traducir sus necesidades, sus intereses y sus ideas a un lenguaje democrático o siquiera racional. Esta división, que a nuestro juicio peca de simplista, conlleva además el grave riesgo de dejar de reconocer la legitimidad del "otro religioso" (Vaggione 2013) y de exacerbar, con ello, la magnitud de las conflictividades ya de por sí presentes entre los sectores que bregan por el cambio cultural y los que más bien se resisten a él.

Con esto, por supuesto, no estamos tratando de obviar ni mucho menos de menospreciar las pugnas culturales (políticas, jurídicas) que tienen lugar hoy día entre sectores sociales disímiles, tampoco los perniciosos efectos que generan las posturas religiosas de corte fundamentalista en nuestras sociedades. Lo que sí deseamos advertir, en cambio, es que convertir al "otro" en enemigo o antagonista no es ni la mejor estrategia para afrontar el conflicto, ni mucho menos la forma más adecuada de contrarrestar la incidencia y la beligerancia de fenómenos como el fundamentalismo religioso. En orden de apaciguar o de canalizar el conflicto a través de vías que no atenten contra la democracia resulta mucho más apropiado, como bien lo recomienda Chantal Mouffe (2006), ver al oponente:

\section{(...) not as an enemy to be destroyed but as an adversary} whose existence is legitimate and must be tolerated. We will fight against his/her ideas, but we will not put into question his/her right to defend them. (...) An adversary is a legitimate enemy, an enemy with whom we have in common a shared adhesion to the ethico-political principles of democracy ${ }^{13}$ (323-324).

Al hacer esto es evidente que no estaríamos soslayando ni desactivando el carácter conflictivo de las disputas, pero al menos estaríamos dándoles la posibilidad de que encuentren salidas democráticas; finalmente, en países como los nuestros, una cantidad nada despreciable de personas encuentran motivaciones de vida profundas en símbolos, creencias o referentes de talante religioso. Si bien asumir al "otro religioso" como un adversario legítimo no representa una solución definitiva a las conflictividades, al menos podría ser
13. El problema, por supuesto, reside en que los proyectos políticos de corte fundamentalista, al menos en nuestros países, suelen caminar en la delgada línea que separa a la democracia del autoritarismo, pues aunque tienden a valerse de la institucionalidad democrática y a moverse dentro de sus márgenes, lo cierto es que al mismo tiempo utilizan dicha plataforma para atentar no sólo contra la convivencia y los valores que tendrían que prevalecer en las sociedades plurales, sino también contra la dignidad humana de amplios sectores de la población. Las posturas fundamentalistas no sólo no reconocen la legitimidad de las demandas ciudadanas planteadas por los grupos que adversan, sino que de hecho tienden a negar, desde una perspectiva metafísica o transcendental, la legitimidad ontológica de las personas que están detrás de dichas reivindicaciones. 
14. Las tendencias religiosas de tipo fundamentalista que atraviesan el subcontinente coexisten hoy no ya únicamente con un conservadurismo cultural más bien inercial y poco militante desde el punto de vista político, sino también con posturas religiosas que desarrollan un genuino esfuerzo por abrazar el pluralismo contemporáneo, por reconocer los derechos de todas las personas y por incorporar dichas

reivindicaciones en el seno mismo de las tradiciones y de las instituciones religiosas. Estos movimientos han venido abriéndose lugar tanto al interior del mundo católico como dentro del mundo evangélico-protestante de los distintos países de la región. A respecto, pueden verse los trabajos de Vaggione (2009); Fuentes Belgrave (2012); Jones y Carbonelli (2012); Bosio, Johnson y Frencia (2017). un buen comienzo para tratar de establecer los puentes comunicativos que contribuirían a zanjarlas. Una separación radical, en contraste, derivaría más bien en una exacerbación de los ánimos, en la anulación de los siempre posibles puntos de encuentro entre los distintos y en el socavamiento general del ordenamiento democrático. Conviene recordar, como bien lo han señalado Vaggione (2013) y Panotto (2017), que ni todas las manifestaciones religiosas de hoy son fundamentalistas, ni todas muestran resistencias al cambio sociocultural o al reconocimiento de los derechos sexuales y reproductivos de toda la población; ${ }^{14}$ por lo cual sería cuando menos cuestionable tratar de alejar a toda manifestación religiosa de los ámbitos de discusión pública en virtud de su supuesto carácter fundamentalista.

Antes que tratar de anular al "otro fundamentalista" por la vía jurídica, cabría preguntarse más bien por las condiciones sociales que estarían alimentando dicha postura y por los mecanismos que podrían idearse con el fin de apaciguarla o de reducirla a su mínima expresión. En esta línea, hemos indicado ya que los fundamentalismos religiosos tienden a surgir sobre todo allí en donde campean la incertidumbre existencial y las necesidades de sentido o comprensión de la existencia; sin embargo, hace falta, a modo de complemento, que digamos algo más acerca de la relación de estas necesidades con los contextos sociales que les sustentan y con las condiciones socioeconómicas que podrían estarles alimentando, pues bien sabemos hoy (Rees 2009; Norris e Inglehart 2004) que más que el mero cambio cultural, lo que lleva a las personas a aferrarse de manera dogmática a referentes de tipo religioso, sobre todo en los países periféricos y semi-periféricos del sistemamundo capitalista, es la inseguridad ontológica que suele producir el constante riesgo vital y las carencias materiales. Tal como fue profusamente demostrado por Pipa Norris y Ronald Inglehart (2004) a partir de un extenso estudio de tipo comparativo mediante el cual procuraron medir la incidencia de la secularización en distintos países del orbe, así como determinar las causas detrás de dicha incidencia, los niveles de religiosidad tienden a presentar una correlación no solamente con el desarrollo humano de las poblaciones, sino también con la vulnerabilidad objetiva y subjetiva que puedan experimentar o no las personas en un contexto dado; las poblaciones y los sectores con mayor desarrollo humano tenderán a aferrarse con menor intensidad a referentes religiosos, mientras que las poblaciones más vulnerables desde el punto de vista económico, político, jurídico, sanitario, natural y, por supuesto, simbólico tenderán a demandar y a consumir con mayor fuerza bienes religiosos de la más diversa índole.

Si bien no es nuestra intención exponer de forma pormenorizada ni los postulados o supuestos teóricos de los que parten Norris e Inglehart ni el detalle de las conclusiones a las que arriban, pues ello trasciende nuestros propósitos actuales, lo cierto del caso es que sí nos interesa retener la relación entre seguridad existencial y religiosidad que detectan en el estudio. Dicha constatación resulta particularmente relevante no sólo para entender por qué en algunos países las expresiones religiosas de orientación dogmática mantienen más arraigo que en otros, sino también para comprender por qué a lo interno 
de un mismo país pueden coexistir sectores sociales favorables al aumento de las autonomía moral y sectores más bien reticentes u opuestos a dicha tendencia o posibilidad.

En el caso latinoamericano es bien sabido, por ejemplo, que las congregaciones pentecostales que desde hace algunos decenios atraviesan nuestros espacios sociales, y que en su gran mayoría destacan por abrazar ideas fundamentalistas de variable intensidad, tienden a ser más numerosas o vigorosas sobre todo allí en donde más arraigadas se encuentran la miseria, la exclusión y la desposesión material y simbólica (Bastian 1997). Además de brindar certezas en medio de la incertidumbre y el desamparo, dichas congregaciones le ofrecen a los sectores más excluidos de las sociedades latinoamericanos la posibilidad de encontrar satisfactores siquiera parciales para algunas de sus necesidades más acuciantes; necesidades que van desde las típicamente materiales o de subsistencia hasta las relacionadas con la construcción de sus respectivas identidades, con la participación en redes afectivas y de solidaridad, e incluso con las relativas al ocio o al esparcimiento (Pineda Sancho 2015), lo cual debe llevarnos a pensar que mientras los Estados y los modelos de desarrollo latinoamericanos no logren incluir a las amplias mayorías y garantizar niveles de bienestar mínimos para toda la población, es muy probable que tengamos que seguir lidiando muchos años más con el fenómeno fundamentalista; ello con independencia de cuanto podamos hacer o no a nivel jurídico para mantenerlo alejado de los ámbitos estatales de decisión.

Posicionarse en contra del fundamentalismo, por consiguiente, pasaría no tanto por una confrontación directa con el "otro religioso" como por una acción política abocada a revertir las profundas injusticias estructurales que sobresalen en los ordenamientos sociales (políticos, económicos) de casi todos los países de la región; lo cual, por supuesto, no implicaría dejar de asumir posicionamientos ético-políticos en favor del reconocimiento pleno de los Derechos Humanos o dejar de adversar con determinación las ideas fundamentalistas que atentan contra la dignidad humana, contra la convivencia social o contra la integridad física de una parte de la ciudadanía, pero sí ayudaría a ver que por sí mismos estos posicionamientos nunca serán eficaces ni para desactivar los fundamentalismos ni para comprenderles en toda su complejidad.

\section{Consideraciones finales}

Tal como lo anunciamos en el apartado introductorio, todo este artículo ha sido el resultado de un esfuerzo abocado a dar cuenta de los rasgos más distintivos del comportamiento de los fenómenos religiosos en el mundo occidental contemporáneo (con énfasis en América Latina) pero sobre todo de una reflexión dirigida a construir, en diálogo con diversos autores y autoras, una vía interpretativa apta para comprender las contradicciones que parecen 
estar contenidas en dicho comportamiento. Muy en contra de aquellas posturas que suelen ver en las actuales formas de reavivamiento religioso o en la vigencia, siquiera parcial, de muchas de las prácticas y creencias religiosas tradicionales una clara señal de no-secularización o de desecularización de nuestras sociedades, creemos haber logrado demostrar que el mundo de hoy no sólo no ha dejado de ser secular, sino que de hecho sigue ofreciendo condiciones favorables para el arraigo y para la profundización de la tendencia.

Aunque llevan razón aquellas voces que tratan de hacer evidente la vigencia de lo religioso en la mayor parte de los países del orbe, así como el hecho de que este ámbito de la experiencia humana no parece estar pronto a desaparecer, como fue tantas veces anunciado en la historia intelectual de Occidente, lo cierto es que, desde nuestro punto de vista, estas fallan tanto a la hora de definir lo que deberíamos entender o no por secularización como al momento de explicar la persistencia de aquellas tendencias que más bien parecen ofrecer pruebas de su plena vitalidad.

En las páginas precedentes hemos argumentado que si estudiáramos la secularización no como un proceso que conduciría inevitablemente a la desintegración absoluta de las expresiones religiosas, sino más bien como una fuerza que desde hace algunos siglos ha estado provocando un desplazamiento sistemático del lugar tradicionalmente ocupado por lo religioso dentro de los ordenamientos sociales, con cierta facilidad llegaríamos a comprender que esta no sólo no ha dejado de tener incidencia en la vida social, sino también que ella es de hecho la causante de que hoy en día, y desde hace ya algunos decenios, puedan coexistir en la realidad concreta fenómenos tan contradictorios como la consolidación práctica de la autonomía estatal respecto de la tutela religiosa y la continuidad; por otra parte, de los proyectos políticos dirigidos a la colonización religiosa de la esfera pública, o como la pluralización/relativización de las creencias y de las prácticas religiosas en contraste con la permanencia de ciertas formas dogmáticas de religiosidad o con el surgimiento de los fundamentalismos religiosos alrededor de todo el globo.

Por extraño que pueda sonar, la secularización, asociada directamente a la modernidad en cualquiera de sus múltiples manifestaciones, es la fuerza histórica que posibilita la confluencia de estos disímiles fenómenos. En la medida que avanza, la secularización provoca importantes transformaciones, no ya únicamente en las condiciones de producción de los símbolos, de las creencias y de los referentes axiológicos de tipo religioso, sino también en las condiciones mismas del creer. Hoy día lo religioso no constituye el garante último de la legitimación de los mundos socialmente construidos, ni tampoco la única o más importante instancia de producción de sentido, de moralidad y de visiones de mundo. Si bien no ha dejado de ser una fuente destacada de sentido, lo cierto es que desde hace algunos decenios ha debido competir tanto con visiones de mundo de carácter enteramente laico como con su propia e inevitable pérdida de plausibilidad. Las personas y los colectivos humanos continúan demandando y consumiendo bienes de salvación, pero ya no necesariamente lo hacen con la misma intensidad o con la misma persistencia con la que pudieron haberlo hecho en otros momentos de la historia. La 
relativización de las creencias, así como la incertidumbre y la duda a ella asociadas, se ciernen como amenazas sobre la vida de casi cualquier persona creyente; aún en la de aquellas categorías poblacionales que con mayor ímpetu abrazan referentes de índole religiosa.

Desde este marco explicativo hemos procurado demostrar, al mismo tiempo, que fenómenos como el conservadurismo o el fundamentalismo religioso no pueden ser tomados hoy ni como la medida de toda forma de creencia, ni tampoco como pruebas de una supuesta desecularización del mundo, pues en el fondo lo que relevan es que en las sociedades modernas lo religioso no sólo no ha perdido del todo sus históricas capacidades, sino que al mismo tiempo ha encontrado en ellas nuevas condiciones para prosperar; por supuesto, no ya como el ordenador último del edificio de la existencia, sino más bien como fuente intermedia de sentido y valores. Las distintas formas de fundamentalismo religioso representan, según esta perspectiva, reacciones negativas a la incidencia de la secularización, al constatado pluralismo axiológico y moral propio de las sociedades modernas y, claro está, a la relativización de las creencias que ha sido y es provocado por los primeros dos procesos.

\section{Bibliografía}

Arguedas Ramírez, Gabriela. 2010. «El (aún) tortuoso camino hacia la emancipación: fundamentalismos religiosos, los derechos humanos de grupos históricamente oprimidos y la lucha por un Estado laico en Costa Rica». Anuario del Centro de Investigación y Estudios Políticos (1): 49-64.

Armstrong, Karen. (2000)2017. Los orígenes del fundamentalismo. En el judaísmo, el cristianismo y el islam. Barcelona: Tusquets Editores.

Bastian, Jean-Pierre. 1997. La mutación religiosa de América Latina. Para una sociología del cambio social en la modernidad periférica. México: Fondo de Cultura Económica.

Bastian, Jean-Pierre. 1999. «Los nuevos partidos políticos confesionales evangélicos y su relación con el Estado en América Latina». Revista Estudios Sociológicos 17(49): 153-173.

Beck, Ulrich. (2008)2009. El Dios personal. La individualización de la religión y el espíritu del cosmopolitismo. Barcelona: Ediciones Paidós.

Berger, Peter. (1967)2006. El dosel sagrado. Para una teoría sociológica de la religión. Barcelona: Editorial Kairós. 
Berger, Peter. 2014. The many altars of modernity. Toward a paradigm for religion in a pluralist age. Berlín: De Gruyter.

Berger, Peter y Thomas Luckmann. (1995)1997. Modernidad, pluralismo y crisis de sentido. La orientación del hombre moderno. Barcelona: Ediciones Paidós.

Blancarte Pimentel, Roberto. 2012. «Religión y sociología; cuatro décadas alrededor del concepto de secularización». Revista Estudios Sociológicos 30: 59-81.

v. 2015. «¿Por qué la religión "regresó" a la esfera pública en un mundo secularizado?». Revista Estudios Sociológicos 33(99): 659-673.

Bosio, María Teresa; Johnson, María Cecilia y Marcela Frencia. 2017. «Disidencia religiosa y libertad de conciencia. Católicas que deciden abortar». RevIISE 11: 99-107.

Casanova, José. 1994. Public religions in the modern world. Chicago: The University of Chicago Press.

Casanova, José. 2012. Genealogías de la secularización. Madrid: Anthropos Editorial.

Corbí, Mariano. 1996. Religión sin religión. Madrid: Editorial PPC.

Corbí, Mariano. 2007. Hacia una espiritualidad laica. Sin creencias, sin religiones, sin dioses. Madrid: Heder Editorial.

Dussel, Enrique. 2004. «Modernidad, imperios europeos, colonialismo y capitalismo. Para entender el proceso de la transmodernidad». Ponencia presentada en la Universidad de Chicago, 24 de abril de 2004.

Dussel, Enrique. 2001. Hacia una filosofía política crítica. Bilbao: Editorial Desclée de Brouwer.

Eliade, Mircea. (1957)1998. Lo sagrado y lo profano. Barcelona: Ediciones Paidós.

Freston, Paul. 2004. Evangelicals and politics in Africa, Asia and Latin America. New York: Cambridge University Press.

Fuentes Belgrave, Laura. 2014. «El cristianismo en la matriz política del Estado: laicidad y autonomía reproductiva en Costa Rica y Nicaragua». Anuario de Estudios Centroamericanos (40): 11-36.

Fuentes Belgrave, Laura. 2012. «Afirmar la autonomía reproductiva en la disidencia religiosa». Íconos Revista de Ciencias Sociales (45): 59-74

Gauchet, Marcel. (1985)2005. El desencantamiento del mundo. Una historia política de la religión. Madrid: Editorial Trotta.

Greeley, Andrew. 2003. Religion in Europe at the end of the second millennium: a sociological profile. New Jersey: Transaction Publishers. 
Habermas, Jürgen y Joseph Ratzinger. 2008. Entre razón y religión. Dialéctica de la secularización. México: Fondo de Cultura Económica.

Hervieu-Léger, Daniéle. (1993)2005. La religión, hilo de memoria. Madrid: Herder Editorial.

Jones, Daniel y Marcos Carbonelli. «Evangélicos y derechos sexuales y reproductivos: actores y lógicas políticas en la Argentina contemporánea». Ciências Sociais Unisinos 48(3): 225-234.

Lenoir, Frédéric. (2003)2005. La metamorfosis de Dios. La nueva espiritualidad occidental. Madrid: Alianza Editorial.

Luckmann, Thomas. (1967)1973. La religión invisible. Salamanca: Ediciones Sígueme.

Luhmann, Niklas. (1977)2009. Sociología de la religión. México: Herder Editorial.

Mardones, José María. 1998. El discurso religioso de la modernidad: Habermas y la religión. México: Anthropos Editorial.

Mouffe, Chantal. 2006. «Religion, liberal democracy, and citizenship». En Political theologies: public religions in a post-secular world, editado por Hent de Vries y Lawrence E. Sullivan, 318-326. New York: Fordham University Press.

Norris, Pipa y Ronald Inglehart. 2004. Sacred and secular. Religion and politics worldwide. New York: Cambridge University Press.

Otto, Rudolf. (1917)1996. Lo santo. Lo racional y lo irracional en la idea de Dios. Madrid: Alianza Editorial.

Panotto, Nicolás. 2017. Religiones, política y Estado laico. Nuevos acercamientos para el contexto latinoamericano. Bogotá: REDLAD.

Pérez Guadalupe, José Luis. 2017. Entre Dios y el César. El impacto político de los evangélicos en el Perú y América Latina. Lima: KonradAdenauer-Stiftung e.V.

Pew Research Center. 2014. Religion in Latin America: widespread change in a historically catholic region. Washington DC: Pew Research Center.

Pineda Sancho, Andrey. 2005. «Producción, oferta, demanda y consumo de bienes simbólicos de salvación en el seno de las iglesias pentecostales costarricenses de hoy (2013-2014): El caso del distrito Uruca». Tesis de licenciatura. Universidad de Costa Rica.

Rees, Thomas James. 2009. "¿ls personal insecurity a cause of crossNational differences in the Intensity of Religious Belief?». Journal of Religion and Society 11: 1-24.

Sagot Rodríguez, Montserrat. 2012. «¿Un paso adelante y dos atrás? La tortuosa marcha del movimiento feminista en la era del neointegrismo y del "fascismo social" en Centroamérica». En Feminismo y cambio 
social en América Latina y el Caribe, coordinado por Alba Carosio, 75100. Buenos Aires: CLACSO.

Tamayo Acosta, Juan José. 2004. Fundamentalismos y diálogo entre religiones. Madrid: Editorial Trotta.

Tamayo Acosta, Juan José. 2006. «Secularización, retorno de la religión y laicidad». En Europa, siglo XXI: secularización y Estados laicos, editado por Miguel Ángel Quintana Paz, 137-148. Madrid: Ministerio de Justicia.

Taylor, Charles. 2011. «Por qué necesitamos una redefinición radical del secularismo». En El poder de la religión en la esfera pública, editado por Eduardo Mendieta y Jonathan Vanantwerpen, 39-60. Madrid: Editorial Trotta.

Taylor, Charles. (2007)2015. La era secular. Tomos I y II. Barcelona: Gedisa Editorial.

Tschannen, Oliver. 1991. «The secularization paradigm: a systematization». Journal for the Scientific Study of Religion 30(4): 395-415.

Vaggione, Juan Marco. 2009. Sexualidad, religión y política en América Latina. Río de Janeiro: Diálogos Regionales.

Vaggione, Juan Marco. 2013. Laicidad y sexualidad. México: UNAM.

Weber, Max. (1905)2012. La ética protestante y el espíritu del capitalismo. Madrid: Alianza Editorial. 